\title{
"Please let me Shape my Fate": Interrogating the Contemporary in Contemporary Imaginative Writing
}

\author{
Hope Eghagha \\ University of Lagos
}

\begin{abstract}
Writers in Africa have a social responsibility to the peoples of their countries. Often they are very enlightened and empowered and in a position to speak up on matters that concern the destiny of the suffering people. This self-chosen role became particularly necessary in the years of military dictatorships. Writers such as Wole Soyinka, Mongo Beti, Chinua Achebe, Athol Fugard, Christopher Okigbo, Ngugi wa Thiong'o, Tanure Ojaide and Ayi Kwei Armah have confronted these issues in different degrees. These concerns are often socio-political, with a tinge of the economic. The cultural aspects of the concerns have been subsumed within new struggles. These writers are concerned with the fate of their countries, and so we can argue that the purpose of writing is the desire to shape the fate of the society. This is what we have termed "let me know my fate". Another concern in this paper is how effectively and successfully can a contemporary writer interrogate a contemporary experience? In other words, can the imagination thrive only when it contends the historical? What are the problems associated with interrogating the contemporary, while the action as it were is still on? Can the African writer afford to wait for history in order to write?
\end{abstract}

\section{Introduction}

In our immediate geographical milieu, a creative writer's intervention in the contemporary politics of his country can be both altruistic and self serving. Altruism arises out of his commitment to the ideals of truth and how the fundamentals of an egalitarian society can be guaranteed and ensured by the leadership class for the benefit of the larger society. To be sure, the ripple effects of the actions of a committed political class will be on the writer himself, who definitely needs a conducive atmosphere to practice his art. It is in this sense that we argue that ultimately the writer's interrogation of contemporary experience can be self-serving. Owing to the constant and perhaps permanent tension between the rulers and the led over the degree of corruption, and some repressive measures taken by governments, writers are compelled to make forceful statements on behalf of the people. By taking a 
firm stand on the issues of the day they court the anger of the government of the day. Andre Brink (1983:51) expresses this in radical terms when he says that "the writer should constantly rebel against the set of circumstances which imperil or curtail the freedom and justice of the individuals in his society and his world". If politics is "the art or science concerned with guiding or influencing governmental policy', then writers have a role to play in the political affairs of their countries.

Any act of injustice perpetrated against the society where a writer lives aims to curtail freedom, the freedom to self expression and achievement. Soyinka asserts that 'justice is the first condition of humanity'. The 'man' in a writer dies if he cannot stand up to the tyranny of the ruling class. This philosophical orientation propelled Soyinka into challenging the civil war drums in 1967. Some other creative writers such as Ngugi Wa Thiong'o, Dennis Brutus, Taban Lo Liyong, Okot P' Bitek, Ken Saro Wiwa, Festus Iyayi, the late Nigeria poet Christopher Okigbo, Robert Serumanga and Leopold Sedar Senghor have participated in the affairs of their nations as activists. Ngugi set up the Karimuthii Theatre and earned ran into trouble with the government of erstwhile Kenyan President Jomo Kenyatta. Senghor was President of Senegal, deeply involved in politics and writing at the same time. Okigbo took up arms on the Biafran side and lost his life during the Nigerian Civil War of 1967-1970. Apart from his acerbic writing which irked the military authorities then in power in Nigeria, Saro Wiwa organised the Ogoni people against the excesses of the Nigerian state and was executed in November 1995. The Ogoni Bill of Rights can be traced to his activism and commitment to the liberation of the Ogoni people from the stranglehold of inequitable federation. In the three examples given the writers in question were so passionate about their beliefs that they got directly involved in the process of interrogating the political processes in their countries.

\section{A Writer's Obligation}

Across the African continent there appears to be a consensus among writers that if the fortunes of society must change then writers cannot and should not leave things completely in the hands of the politicians or the military. Society within the context of this essay refers to an enduring and cooperating social group whose members have developed organized patterns of relationships through interaction with one another; it is also a community, nation, or a group of people who have common traditions and collective interests. Thus society in context may refer to the different nations on the African continent or specifically Nigeria as evinced from the selected writers. Penina Mlama (1990:8) observes that "we are talking about an Africa that is ripped apart by an economic, social, and cultural crisis...Ours is an Africa where many of our leaders have sold our countries wholesale to international capital, giving the control over our economies and consequently our welfare, indeed our lives, to the IMF or the World Bank". In a few cases, there has been direct and active 
participation in the political process of nation building. Such writers as the late Nigerian poet Christopher Okigbo, late Agostinho Neto (former President of Angola), late Dr. Leopold Sedar Senghor (former President of Senegal) Chinua Achebe, and Wale Okediran (currently in the Nigerian House of Representatives) have participated directly in the political process of their countries. Indeed the poets Neto and Senghor rose to the top of the political hierarchy in their countries both as Presidents.

Soyinka has been active as a social mobilizer and opinion moulder in Nigeria. Achebe joined the Mallam Aminu Kano-led Peoples' Redemption Party (PRP), a party with mass appeal in the Second Republic as a way of identifying with the people. Ngugi's Karumithii outdoor theatre was a political statement against the dictatorial government of Jomo Kenyatta. He was ultimately arrested and forced into exile. Thus, there have been two levels of participation. There is participation as active politicians as men and women wielding power and as critics of the political class. Kenyan writer Ngugi Wa Thiong'o has explicitly and extensively done an exegesis on this subject. By and large, writers have made enormous contributions through their writing, through documenting experience and drawing attention to the ills of society.

One of the fundamental questions we wish to address in this paper is how effectively a writer can interrogate and successfully depict an on-going or contemporary experience. Sometimes with the benefit of hindsight and reflective thinking, a writer may be better placed to evaluate an occurrence before capturing it in imaginative writing. However, if the writer feels that silence would be tantamount to acquiescence, then the spirit of the muse has to be given freedom. The decisions of the political class and their implications impinge on the lives of citizens, including the lives of writers. The ambience created by political decisions allows the writer to thrive or sink into oblivion. During the apartheid years in South Africa writers played a fundamental role in drawing the attention of the world to the dehumanising effects of that political ideology.

Soyinka has successfully interrogated military rule and dictatorship in such works as Kongi's Harvest and A Play of Giants. Achebe has also achieved such a feat in A Man of the People and Anthills of the Savannah. In a sense Achebe's two novels on this subject have been predictive. While the first predicted the inevitability of a military incursion, the other reflects on the transition of the military into civilian or 'democratic' rulers. Okey Ndibe's Arrows of Rain interrogates the presence of dictatorship in an African state also.

Most of the poems published by young writers in Nigeria are invariably concerned with socio-political issues. The injustice perpetrated in the Niger Delta through the exploitative nature of the Nigerian state has captured the imagination of poets of the new generation. For example, the new generation of poets from the Niger Delta have focused on environmental issues of their 
region. These poets cannot isolate themselves from the currents and undercurrents of their people. Activism is virtually imposed on them.

Interrogating the contemporary in contemporary writing is symptomatic of the urgency, of motion and energy. It is a sign that the reverberations of contemporary life are capable of affecting the psyche of the living and there is a need to draw attention to, to paint a mirror-canvas which is reflective of the dynamics of socio-political realities.

\section{The Writer as Peoples' Advocate}

Most African writers have taken sides with the people against the governments of the day. This they do by presenting the 'unpopular' side in their works. In most of African countries, there is a subtle threat to writers on the views they express. This is what Bjornson (1994: xiv) refers to in the Cameroonian experience when he writes that "authors must assume responsibility for the ideas they express - a grave responsibility in countries where the state does not tolerate dissenting opinions". In such plays as A Play of Giants, Our Husband has Gone Mad Again, and Morountodun, the viewpoint is often against the powers that be. In some instances, governments have become so infuriated as to lock up writers for expressing views that are contrary to the position of the establishment. Some other writers have had to flee into exile for fear of their lives. Some writers who have expressed such a fate are Wole Soyinka, Ngugi wa Thiong'o, Nurudeen Farah, the late Mongo Beti, and Bessie Head.

The tradition of exploring the contemporary in contemporary writing in Africa can be traced to the struggle for independence when writers had to pitch their tent with the nationalists struggle. Colonialism denigrated African customs and traditions, imposing in the process a new religion and way of life. The theme of culture conflict was evident even predominant in the earliest works of Nigerian writers. In works like Arrow of God (Achebe), The Lion and the Jewel (Soyinka), and The Dilemma of a Ghost (Ama Ata Aidoo), the dynamics of interracial conflicts are played out often in favour of the African viewpoint. The negritude movement also explored the contemporary, reasserting and reaffirming the authenticity of the African way of life. It is true that there were writings that strived to justify colonialism and explain the status quo. Udenta's (1993: xvii) detailed study of this phenomenon does bear some reference. He writes that "during the colonial period, three different types of literature flourished: the literature of the colonial imperialist, intent on de-structuring and collapsing the integral ontology of the colonized, and thereby justify colonialism". He goes on:

The literature of the mission - trained enthusiastic writer, eager to rationalize the 'primitivism' of his people and the civilizing imperatives of imperialism, and thereby prove to his masters that he is an authentic 'born again'; and finally, 
the literature of cultural nationalism, groupable under the sub-categories of liberal humanist ideology of the emergent liberal social critic, and the literature of commitment, of the negation of all that colonialism stands for.

With the openness of society particular with the advent of liberal democracy the incidence of writers going to jail for expressing dissenting views has reduced somewhat. Yet, freedoms must be guarded. It is for this reason that the charges of sedition levelled against two Nigerian journalists by the incumbent Nigerian government must be fought vigorously by the free world. Gradually, the present administration has shown that it can be impatient with dissenting views. The laws on sedition were passed during the colonial era when the colonialist wanted to stifle freedom of speech. Most constitutions of African nations spell out the fundamentality of freedoms, much in line with the African Charter of Human Rights. Although these freedoms have always been expressed or mouthed, they have not always been guaranteed. Most African nations would not want to be caught on the wrong side of history because of the approval rating which they so much crave from international organisations and from the undeclared 'policeman of the world - the United States of America'.

\section{The Writer as Incorruptible Judge}

A writer is often perceived as impartial and truthful, an upright judge who would always be impartial. For the art of creative writing compels truthful to one's conscience. The Muse will not tolerate nor inspire fraud in any genuine writer. What a writer has to say is important only to the extent that he says it truthfully. It is for this reason that writers are referred to as the unacknowledged legislators of the world. To legislate fairly the writer has to be familiar, indeed must have intimate knowledge of his environment, the cultural and social mores, and value system of the society. He must also be at home with universal paradigms and how these can fit into the society he lives in.

The creative imagination evaluates subjects and phenomena, both introspectively and retrospectively, before putting pen and paper. It interrogates objectively, like a judge of character before taking sides. Sometimes he knows that the pressures of different interest groups could make politicians take the wrong decisions. For example, the pressure of the International Monetary Fund (IMF) made the Nigerian government of President Ibrahim Babangida devalue the naira by adopting the now discredited Structural Adjustment Programme (SAP). Soyinka's romance with that administration as Chief Executive of the Federal Road Safety Corps (FRSC) ended soon afterwards.

Certain factors have helped to shape the conscience or world view of writers from time immemorial. In the African situation, the twin experiences 
of slavery and colonialism have been instrumental to the emergence of the existing forms of literary dialogue. Contemporary Africa therefore is a sum of its memories, its history and antecedents. It is in this context that we define history as a chronological recording of significant events which often includes an explanation on the causes of these events. The crisis of rising expectations and increased frustration arising from the failure of the state to meet the hopes raised in the struggle for independence has featured in the thematic concerns of African writers. Sometimes the very idea of race affects how a writer interprets historical occurrences and how they are presented in his works. This is particularly true in the South African situation that fought the obnoxious policy of apartheid for ages. Dennis Brutus, Ezekiel Mphahlele, and Athol Fugard for example, helped to bring the plight of South Africans under apartheid to the attention of the world.

The image of the writer as a judge of character is central to our thematic concerns here. The ethical standards of society are invariably reflected in imaginative writing. As we observe the characters that people the landscape of the artistic works of writers, we immediately realise who has the sympathy of the writer or whose views represent the viewpoint of the writer. The characters are put on a scale and we weigh them through their actions, judging their character through behaviour. In Achebe's A Man of the People we frown at Chief Nanga's excesses and indeed the excesses of the politicians. We are so disenchanted with them that when the soldiers strike we adopt a 'serves you right' attitude. The writer has been able to set the character against the moral and ethical standards of society and we conclude that they fall short of expectation. Achebe encapsulates our reaction in the saying 'Joshua has taken enough for the owner to notice' after Joshua was caught trying to cheat the blind man.

\section{Propaganda Writing}

Attempting to develop a theme around contemporary issues may lead to appropriating propaganda methods. Once a creative writer indulges in propaganda writing he can no longer serve or perform the function of the incorruptible judge. Although in fictive writing this rarely occurs, it is an option open to a group or government bent on imposing or adverting a particular viewpoint. Examples occurred during the Cold War years, both in the West and especially in the Soviet Union. The powers-that-be sometimes solicits the services of writers for propaganda purposes. This happens in a state of dictatorship, where the interests of the rulers will be served by such partisan writing. This represents counter discourse and it is often designed to distort the truth. Such a situation may arise when the ruling group or junta wishes to counter the views of an established and influential writer by employing the paid services of a 'patriotic writer' whose viewpoint must be used to persuade persons or audiences outside the immediate geographical milieu. 
Creative writers often have credibility until they sell off their birth right for the proverbial mess of pottage. In other words, credibility and integrity are a 'given' in the engagement between the writer and the tool. But the audience is also on guard, sniffing as it were, which side the writer is going to be on. 'Them' and 'us' are palpable divides in most African countries, the dividing barrier being access to wealth and political power. Power is inexorably deployed against the mass of the people, repudiating the unwritten social contract between the rulers and the people. Ngugi captures this alienation, this politics of exclusion in the 'This Time Tomorrow' where the government of the day has marked a certain residential area for demolition. The insensitivity of the government as depicted in this play is a replication of the experiences of most African nation. The uncertainty of the times is captured in the title, This Time Tomorrow; what becomes of us, what shall we be, what is the future and current fate of the African child, of the African man. It points fingers in the direction of exile from the fortunes, the positive destiny which Providence had created for the mass of the people. Disastrous policies alienate the people from the joys of existence.

The very decision therefore to venture into creative writing imposes a burden on the African writer. It is in this context that Bjornson (1994:326) writes that for Mongo Beti,

the act of writing becomes a gesture that sweeps away false images and lays the groundwork for a rational understanding of contemporary Africa in its socio-historical context. On the basis of this understanding, Africans can participate actively in the struggle for freedom and identity that, according to Beti, each people must undertake for itself.

Andre Brink, (1983:13) writing about the writer's responsibility during the apartheid era also says that a writer's 'presence in a world where more and more violence is solving fewer and fewer problems, makes the writer not less, but more necessary'. The problems are immediate, requiring the urgent attention of a surgeon, with a scalpel in hand ready to excise the odious and putrefied or putrefying segments of the anatomy. At the other end of the spectrum are the men of power who wait with devilish impatience to unleash darkness into the theatre by switching off power supply while the surgeons are about their work. Invariably the patient dies on the operating table and the surgeons migrate in droves to other lands.

The metaphor of the surgeon for the creative writer could be problematic, even ambitious, and far-fetched. Is creative writing effective enough to expel unwanted or damaged tissues from the polity? This self-defeating question that seeks to annihilate the very thesis of my presentation becomes apposite against the background of doubts about the number of persons who have 
access to this medium. For, the level of poverty in the land and a pervasive culture of philistinism have excluded a sizeable percentage of the population from the aesthetics of the world of the living papyrus. With leaders of the African continent, portrayed by Ayi Kwei Armah in images of the ugly in The Beautyful Ones Are Not Yet Born; by Achebe as the 'problem' in The Problem with Nigeria; and by Ola Rotimi as madmen in Our Husband has Gone Mad Again, we come away with the perception that the typical African writer has no illusions about the calibre of persons who on the saddle of leadership. But as Armah asks, 'How long shall Africa be cursed with its leaders'?

\section{The Present as Memory-Making}

The process of interrogating the present implies the making of memory. For the future to be meaningful there is the need to make memories, in form of actions and thoughts. Thus a writer's personal or general history can help to shape his consciousness. General history refers to the history of his ethnic group or nation or religion and religious bias. These may also influence his disposition to or perception of the larger issues of the day. Ngugi's class interpretation of historical struggles for example, is determined by his personal experience. The same applies to the Nigerian poet, Niyi Osundare who openly refers to his 'agrarian and peasant upbringing' in Ikere-Ekiti of Ekiti State Nigeria.

Etchings in form of art works and narratives establish a link between the contemporary and the future. Memory is fundamental to growth, identity definition, and recognition. Man's ability to recognise the present as it is implies a readiness to confront the past and prepare for the future. When Achebe says that as Africans, we 'must know where the rain began to beat us' he implies that we ought to understand both our antecedents and contemporary experience. It is only a writer who experiences the contemporary that can understand the hiatus between the autochthonous values of the past and the influx of foreign values into the land.

For a writer who is not simply documenting the present as news, the present has to be vigorously interrogated and analysed with a view to distilling the truth. If he is compelled to wait, the consequences of this wait may be fatal to the people whose fate he wants to help to shape. To achieve this, a writer has the innate capacity to withdraw from the fanfare of the moment, examine it like a sculptor and polish the final work for the benefit of humanity. This is the process of self-criticism, where a writer examines the covert and overt meanings of his work. He is able to critically assess what his imagination has produced from raw experience and how effectively he has deployed the tools of language to achieve his objectives.

\section{Metaphors, Symbols, Myths and Paradigms}

Through the use of metaphors, symbols and paradigmatic re-creations, creative writers capture the present for the benefit of the future. Using figures 
of speech and profound imagery help to broaden the appeal of the subject without necessarily obfuscating the message. Metaphors can operate at the overall level, that is, at the level of the entire work. It could be couched in allegorical terms, drawing from myth and mythology, as Osofisan has done in Morountodun and Another Raft.

A symbolic representation is another approach with which a writer could grapple with topical issues, particularly if his physical security is threatened. Within this approach the present could be situated in the past, with nuances and allusions pointing in the direction of the present. Kongi's Harvest, for example, adopts this approach. Power, which is the focus of the work, is symbolically in the hands of the dictator who also wants to appropriate traditional forms of power. To achieve his goal, time has to be adjusted. His disgraceful end is typical of all dictators.

I have employed the mythic references in the story of a tyrant king in my ethnic background for the purpose of making a statement about the contemporary in my latest play, Onowawi Shall Rise Again. I have used the historico-mythical story to explore the Saro Wiwa execution which the Abacha regime carried out in 1995. Also, I have concerned myself with environmental issues of the Niger Delta. In the play under reference, 'stopping a falling tree' becomes a symbol of public execution. On the part of the ruler, it epitomizes callousness and lack of respect for human life, while for the citizenry; it is an indication of falling out with the oppressor, the man who pulls the levers of power. Set in Okpe land, a tyrant king who wants to get rid of an opponent would ask him to stop a falling tree, to prevent a falling tree from reaching the ground. This story, which derives from Okpe history and myth, is said to have occurred centuries ago. Of course the tree usually crushes the opponent to death. The question is: what form of thinking propels a man, a king into exterminating his citizens in such a horrendous manner.

\section{Conclusion}

The artistic imagination feeds both on the present and on history, depending on the nature of the subject and the socio-political circumstances of the writer. Contemporary events could become a spur, an inspiration to explore thematic preoccupations that have broad applications to the canvas of human experience. Also, a contemporary experience could find parallels in the historical or mythical past of a people, just as Osofisan does in Morountodun, using the myth of Moremi to explore the Agbekoya uprising of 1969. In such circumstances, the writer appropriates history as a vehicle for participating in the reconstruction of modern society. Except writers reflect the concerns of contemporary writing, they may become irrelevant to society. The immortal Achebe (1975:78) sums up the responsibility of the African writer when he says: 
It is clear to me that an African creative writer who tries to avoid the big social issues of the contemporary Africa will end up being completely irrelevant like that absurd man in the proverb who leaves his house burning to pursue a rat fleeing from the flames.

The African writer, therefore, cannot divorce himself from the socio-political currents of his time and society. Apathy or a delusion with romantic issues could be dangerous to the survival of the state itself. This tradition developed during the years of the military when there was no official opposition to the acts of brigandage committed by military adventurers. A topical subject can be handled by a creative writer who is conscious of his role both as recorder of experience and spokespersons for the voiceless majority of the people. It is a job of the conscience for which there is no immediate reward, not even the reward of the mass of the people purchasing the very work itself and compensating the writer financially.

\section{References}

Achebe, Chinua (1988), Anthills of the Savannah. Ibadan: Heinemann. (2000), Home and Exile London: Oxford University Press. (1975), Morning Yet On Creation Day. London: Heinemann.

Bjornson, Richard (1991), The African Quest for Freedom and Identity. Bloomington: Indiana University Press

Brink, Andre (1983), Writing in a State of Siege- Essays on Politics and Literature New York: Summit Books.

Eghagha, Hope, (2006), Onowawi Shall Rise Again Ibadan: Ababa Press.

Mlama, Penina M.(1990), "Creating in the Mother-Tongue: The Challenges to the African Writer Today" Research in African Literature Vol. 21 No. 4.

Ndibe, Okey (2003), Arrows of Rain. Ibadan: Heinemann.

Osofisan, Femi (2001), Insidious Treasons - Drama in a Postcolonial State. Ibadan: Opon Ifa Publishers.

Said, Edward, (1994). Culture and Imperialism. New York: Vintage Books.

Thiong'o, Ngugi Wa, (1981), Writers in Politics. London: Heinemann.

Udenta, O. Udenta (1993), Revolutionary Aesthetics and the African Literary Process Enugu: Fourth Dimension Publishers.

Note: The Esiri Dafiewhare Scholarship is based in York and alludes to this in the introductory remarks. 